\title{
CUPRESSINOXYLON JIAYINENSE, A NEW SPECIES OF THE LATE CRETACEOUS FROM HEILONGJIANG PROVINCE, CHINA
}

by

\author{
Wang Ru-feng ${ }^{1}$, Wang Yu-fei ${ }^{2} \&$ Chen Yong-zhe ${ }^{1}$
}

\begin{abstract}
SUMMARY
Cupressinoxylon jiayinense spec. nov, a new species of silicified coniferous wood, is described from the Late Cretaceous in Jiayin County, Heilongjiang Province, Northeast China. The growth rings are distinct. The transition from earlywood to latewood is gradual. Rays range from 1 - to 2-seriate, and are 4-68 cells high. Both horizontal and tangential walls of ray cells are smooth. The cross-field pitting is cupressoid. There are 2 or 3 pits per cross field. Ray tracheids are rarely present. Wood parenchyma is abundant and diffuse. Resin canals are absent. These features indicate affinities with Cupressaceae, specifically with some members of the extant genus Cupressus.
\end{abstract}

Key words: Cupressinoxylon, Late Cretaceous, Heilongjiang.

\section{INTRODUCTION}

The form genus Cupressinoxylon was established by Göppert (1850) to describe the gymnospermous fossil woods that were composed of tracheids and axial wood parenchyma but lack resin canals, including all the fossil woods belonging to Cupressaceae, Taxodiaceae and Podocarpaceae. Gothan (1905) and Kräusel (1949) amended it and established another genus, Podocarpoxylon (Gothan 1905) to accommodate the fossil woods belonging to the Podocarpaceae. Although Greguss (1955) suggested that the woods of Cupressaceae could be distinguished from those of the Taxodiaceae by characteristics such as bead-like thickenings on the tangential walls of ray cells, there is no consistency with respect to this or other characteristics that are claimed to distinguish woods of the two families (Steward \& Rothwell 1993). Based on their wood structural similarities, both families are more closely related to one another than to any other conifer family. On the basis of this opinion Seward (1919) maintained the form genus Cupressinoxylon for all woods showing characteristics of the Taxodiaceae and Cupressaceae (Steward \& Rothwell 1993). Nevertheless, many fossil woods clearly related to modern genera of both families have been assigned to Cupressinoxylon, Tetraclinoxylon, Chamaecyparioxylon, Palaeocallitroxylon, Callitroxylon, Libocedroxylon, Metasequoioxylon, Taxodioxylon, Sequoioxylon etc., to show their wood anatomical similarities by several authors (Vaudois \& Privé 1971; Du Nai-zheng 1982).

1) College of Life sciences, Shandong University, Jinan 250100, China.

2) Institute of Botany, Chinese Academy of Sciences, Beijing 100093, China. 
The silicified woods studied in this paper are assigned to a new species of Cupressinoxylon because they closely resemble some species of Cupressus in their wood anatomy.

\title{
MATERIALS AND METHODS
}

The present investigation is based on the study of two samples of silicified woods, HLJ-01 in good preservation and HLJ-03 in poor preservation, discovered from the south bank of Heilongjiang River, Taipinglinchang, Jiayin County, Heilongjiang Province, China. The specimens are dated from the Jiayin group, Late Cretaceous (Zhang Zhi-cheng 1983; Li Wei-rong 1986). The Jiayin group contains three Formations named by their localities, the Yongantun Fm., the Taipinglinchang Fm. (overlaid by Yuliangzi Fm.), and the Yuliangzi Fm. where dinosaur skeletons have been excavated (Zhang Zhi-cheng 1983; Li Wei-rong 1986). The strata are well exposed along the riverbank and their sections are simple in structure and relatively continuous. The flora from the Jiayin group consists of Thallites jiayinensis Zhang, Equisetum? sp., 'Asplenium' dicksonianum Heer, Arctopteris sp., Cladophlebis sp., Ginkgo adiantoides (Unger) Heer, Taxodium olrikii (Heer) Brown, Metasequoia disticha (Heer) Miki, Podocarpus $\mathrm{cf}$. tsagajanicus Krassilov, Pityophyllum sp., Cupressinocladus sp., Carpolithus sp., Macclintockia cf. trineris Heer, Trochodendroides arctica (Heer) Berry, T. smilacifolia (Newberry) Kryshtofovich, Platanus densinervis Zhang, P. sinensis Zhang, 'Platanus' raynoldsii Newberry, Tiliaephyllum cf. tsagajanicum (Krysht. et Baikov) Krassilov, Pterospermites orientalis Zhang, P. heilongjiangensis Zhang, Viburnum cf. contornum Lesq., Nordenskioldia cf. borealis Heer, Laurophyllum sp., Quereuxia angulata (Newberry) Kryshtofovich, Dicotylophyllum sp. (Zhang Zhi-cheng 1983). The most dominant group of the Jiayin flora are the angiosperms, of which Trochodendroides occurred abundantly. The gymnosperms are represented only by Coniferales and one species of Ginkgoales.

The peel method (Zhu Wei-qing 1983) was used in making transverse, radial, and tangential sections of the silicified woods which were preserved at the Department of Paleobotany, Chinese Academy of Sciences, Beijing. The photomicrographs were taken with Olympus photomicrographic equipment. Wood sections of extant conifers for comparative studies were provided by the Institute of Wood Industry, Chinese Academy of Forestry.

\section{SYSTEMATIC DESCRIPTION}

\author{
Class: CONIFEROPSIDA \\ Order: Coniferales
}

Family: Cupressaceae

Cupressinoxylon (Göppert) Gothan (1905) 


\section{Cupressinoxylon jiayinense, spec. nov.}

Holotype: HLJ-01

Repository: Department of Paleobotany, Institute of Botany, Chinese Academy of Sciences, Beijing, China

Type locality: Jiayin County, Heilongjiang Province, China

Stratigraphic horizon: Late Cretaceous

Etymology: From Jiayin County

\section{Diagnosis:}

The wood consists of tracheids, axial wood parenchyma and rays. The growth rings are distinct, the transition from earlywood to latewood is gradual. Rays are 1- or 2seriate, and 4-68 cells high. Both horizontal and tangential walls of ray cells are smooth. The cross-field pitting is cupressoid, 2 or 3 pits per field. Wood parenchyma is abundant. Resin canals are absent.

\section{Description:}

Tracheids - The growth rings are distinct. The transition from earlywood to latewood tracheids is gradual (Fig. 1). Tracheids of earlywood are squarish to rectangular with round angles in transverse view. The diameter of tracheids is $17-63 \mu \mathrm{m}$ in tangential direction, and $34-69 \mu \mathrm{m}$ in radial direction. Bordered pits on the radial walls of tracheids are circular, 1- or 2-seriate. Uniseriate pits are separate, sometimes slightly contiguous. Biseriate pits are opposite (Fig. 4). The pit pores are round or elliptical with a diameter of 4-6 $\mu \mathrm{m}$. Crassulae are distinctly present (Fig. 4). Latewood zones are 5-20 cells wide, and usually consist of more than 12 layers of thick-walled cells. The average tracheid diameter is $21 \mu \mathrm{m}$ in radial direction, and $28 \mu \mathrm{m}$ in tangential direction. Bordered pits with round apertures on the radial walls are uniseriate. The tangential walls of latewood tracheids are also pitted, but the number of pits is fewer than those on radial walls (Fig. 7).

Wood parenchyma - Axial wood parenchyma is abundant and strands are usually scattered in transverse section (diffuse). They appear to be about the same size as the tracheids, but are more nearly square. The parenchyma cells are about $25 \mu \mathrm{m}$ in diameter and $155 \mu \mathrm{m}$ tall and sometimes contain dark gummy deposits. Their terminal walls are unpitted (Fig. 5).

Wood rays - Prominent, usually uniseriate, sometimes biseriate in part, 4-68 cells high (Fig. 6). Both horizontal and tangential walls of ray cells are smooth (Fig. 2). Radially ray cells are about $75 \mu \mathrm{m}$ long and $16 \mu \mathrm{m}$ high, each ray cell spans 3-5 tracheids. Cross-field pits are predominantly cupressoid, but occasionally taxodioid. In each cross field, there are 2 or 3 pits in a line; the pits are elliptical and oriented obliquely, with the long radius of about $6 \mu \mathrm{m}$ and the short radius of $3 \mu \mathrm{m}$ (Fig. 3). Ray tracheids are rarely present. Their inner walls are smooth.

Resin canals - Both horizontal and vertical resin canals are absent. 

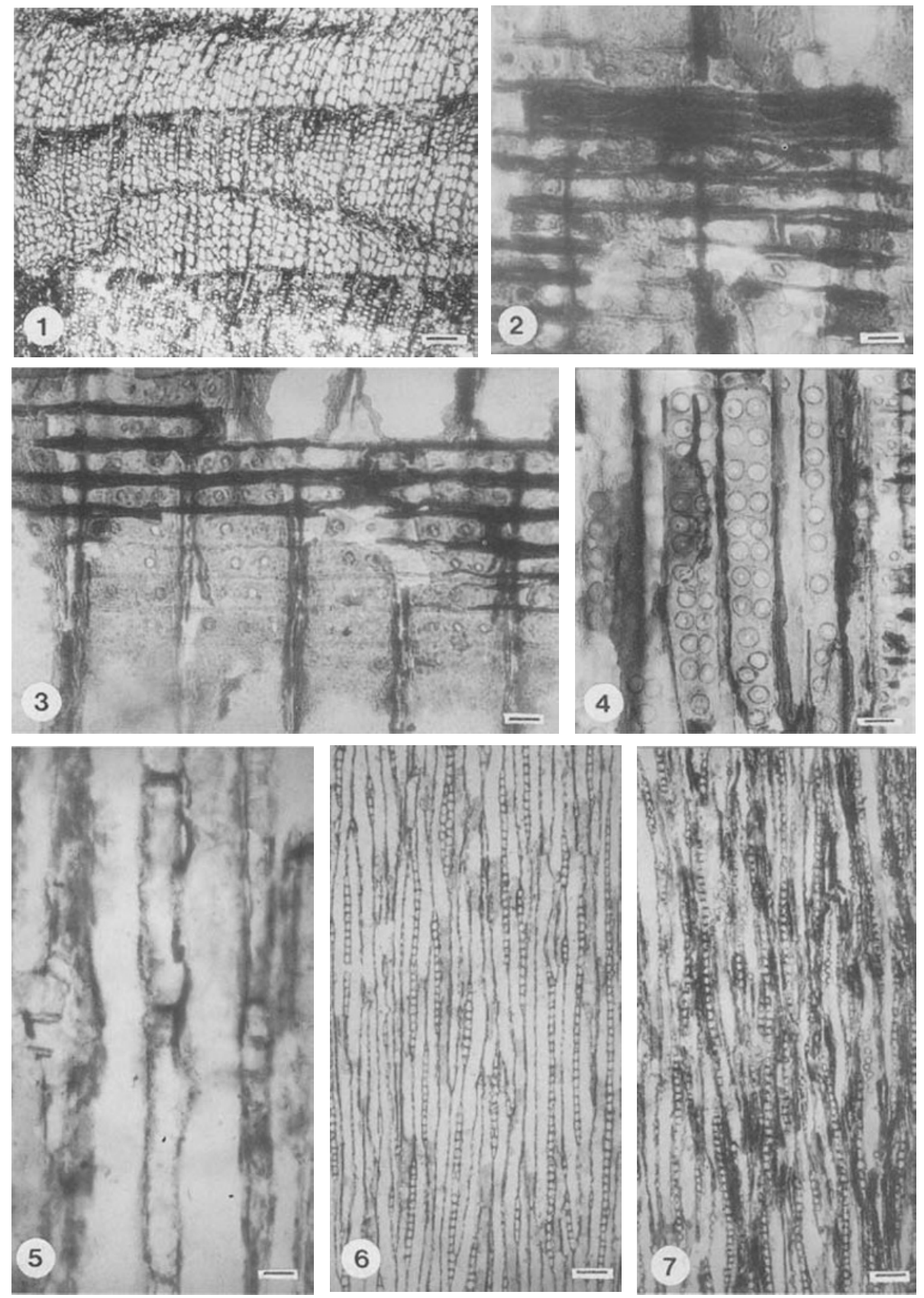


\section{COMPARISONS WITH OTHER CONIFEROUS FOSSIL WOODS}

The wood structure of the new species is characterized by abundant axial wood parenchyma, smooth-walled ray cells with cupressoid cross-field pits and absence of resin canals. These characteristics completely coincide with the generic features of $\mathrm{Cu}$ pressinoxylon as described by Gothan (1905). In the genus Knowlton (1919) listed 27 species of Cupress(in)oxylon from North America, Kräusel (1919) recorded over 170 species, which were variously referred to Cupressinoxylon, Cupressoxylon and Cupressus. In many cases the generic names, Cupressinoxylon and Cupressoxylon, have been used synonymously in describing the same species. Many of these taxa were not determined as to species. Even some of the determinations were based on poorly preserved or scanty material. Therefore, it was not surprising that the identifications cannot be authenticated (Lutz 1930). Kräusel (1919) limited the number of forms which may be referred with reasonable certainty to Cupressinoxylon to 17 species. Stopes (1915) listed 4 species from Lower Greensand, Isle of Wight. Vaudois and Privé (1971) summarized the main work about Cupressinoxylon and finally enumerated 44 species which had been named scientifically. Compared with these species, HLJ-01 is closely related to four of these species but the discrepancy between them is also distinct (Table 1).

1. Cupressinoxylon cupressoides Kräusel (1919). According to the description given by Lutz (1930), it differs from HLJ-01 chiefly in that its parenchyma cells occur in tangential bands of 2 or 3 cells thick. And the pits on the tangential walls of the tracheids are numerous. Its rays are usually low, the highest only had 23 cells (Lutz 1930).

2. Cupressinoxylon vectense Barber (1898). The main differences with HLJ-01 are: In $C$. vectense, the number of pits per cross field is usually 1, but 2 or 3 in HLJ-01. In $C$. vectense, the rays are only 1-12 cells high but they are 4-68 cells high in HLJ-01. Furthermore, in $C$. vectense the horizontal walls of ray cells are thin, but thick in HLJ-01 (Barber 1898; Seward 1919; Shimakura 1936).

3. Cupressinoxylon megeeci Knowlton (1889) seems to be similar to HLJ-01 in some respects. The chief differences from HLJ-01 are as follows: 1) The simple pits in cross field. 2) Its wider rays (1-3-seriate). 3) Bordered pits on the radial walls of tracheids are 2- or 3-seriate (Stopes 1915; Seward 1919).

4. Cupressinoxylon koettilitzi Seward (1919) differs from HLJ-01 in its alternate bordered pits on the radial walls of tracheids. Elsewhere, the simple cross-field pits and low rays ( $1-25$ cells high) also indicate their incompatible characteristics (Seward 1919).

Fig. 1-7. Cupressinoxylon jiayinense. - 1: Transverse section, showing the distinct growth rings and transition from earlywood to latewood. -2 : Radial section, showing the walls of ray cells. - 3: Radial section, showing cross-field pitting. -4 : Radial section, showing the pits on radial walls of earlywood tracheids. - 5: Radial section, showing axial wood parenchyma cells. 6: Tangential section, showing distribution of xylem rays. -7 : Tangential section, showing the pits on tangen-tial walls of latewood tracheids. - Bar equals $90 \mu \mathrm{m}$ in Fig. 1; $15 \mu \mathrm{m}$ in Fig. 2; $18 \mu \mathrm{m}$ in Fig. $3 ; 30 \mu \mathrm{m}$ in Fig. $4 ; 25 \mu \mathrm{m}$ in Fig. $5 ; 80 \mu \mathrm{m}$ in Fig. $6 ; 80 \mu \mathrm{m}$ in Fig. 7. 


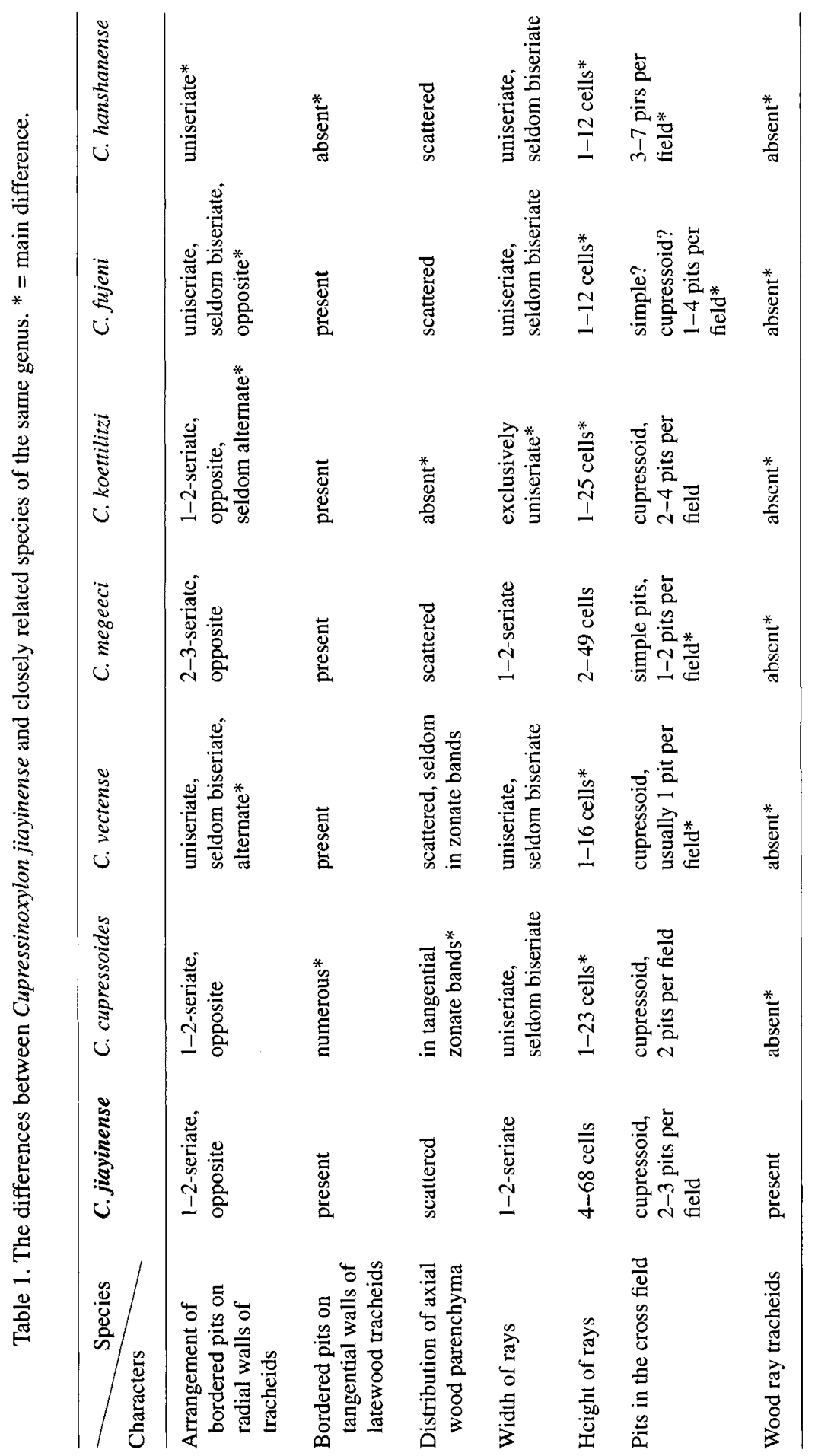


In China, two other specimens of Cupressinoxylon, $C$. hanshanense Zhang et Cao (Zhang Shan-zhen \& Cao Zheng-yao 1986) and C. fujeni Mathews et Ho (Sze 1963) were also reported. In $C$. hanshanense, the bordered pits on the radial walls of tracheids are slightly separate and arranged in one line. Bordered pits on the tangential walls of tracheids are absent. Rays are uniseriate, $1-12$, usually $4-6$ cells high. There are usually 3 or 4 pits per cross field, occasionally 6 or 7 (Zhang Shan-zhen \& Cao Zheng-yao 1986). So there is much discrepancy between $C$. hanshanense and HLJ-01. In C. fujeni, the rays are very low (1-12 cells high). The cross-field pits are simple, and the central part of ray cells is swollen. Sze suggested that these characteristics show its affinities to Araucariaceae (Sze 1963).

The detailed comparison with other fossil woods of Cupressinoxylon indicates that the specimen HLJ-01 is different from all of them in some features such as the number and the size of cross-field pits, the height of rays, etc. Hence, it is named here as $C$. jiayinense spec. nov. The specific name derives from its occurrence in Jiayin County of China.

\section{AFFINITIES WITH EXTANT CONIFERS}

The wood structure of Cupressinoxylon jiayinense is similar to that of three extant genera of Cupressaceae, viz. Cupressus, Chamaecyparis and Biota. However, there are wood anatomical differences between them. In Chamaecyparis the growth rings are rather narrow and the cross walls of axial parenchyma cells have nodular thickenings, while in $C$. jiayinense the growth rings are much wider. There are no nodular thickenings on the cross walls of axial parenchyma cells. In Biota, the wood rays are low (1-6 cells high) and the horizontal walls of ray cells are usually pitted. In Cupressus, the horizontal walls of ray cells are rather thin and the pits on the radial walls of earlywood tracheids are usually uniseriate, while in $C$. jiayinense the horizontal walls of ray cells are thick and the pits on the radial walls of earlywood tracheids are 1- or 2-seriate. It is obvious that the wood structural differences between C. jiayinense and Cupressus are much smaller than those between $C$. jiayinense and the other genera of the Cupressaceae. Cupressinoxylon jiayinense and Cupressus possess many common characters in wood structure, including wide growth rings, gradual transition from earlywood to latewood, higher wood rays with cupressoid cross-field pitting, and ray tracheids. Therefore, Cupressinoxylon jiayinense might be regarded as an individual member of Cupressaceae, which has a close relationship with Cupressus.

\section{ACKNOWLEDGEMENTS}

We are very grateful to Prof. Cheng-sen Li for his help in the fossil wood collection and discussion of the manuscript. We express our gratitude to Prof. Wei-qing Zhu for his experienced counsel on the peel method and Prof. Jia-ju Yang from the Institute of Wood Industry, Chinese Academy of Forestry, who provided extant conifer wood sections for comparative study. Thanks are due to Dr. Jin-zhong Cui, Dr. Jin-xing Lin and Prof. Ming-yu Xu for their many helpful suggestions about the paper. This work was supported by grants from the National Natural Science Foundation of China No. 39300007 and No. 38321001 , SFPPAS No. 9218 and partly from the Young Scientists Lab of Plant Origin and Environmental Changes. 


\section{REFERENCES}

Barber, C.A. 1898. Cupressinoxylon vectense, a fossil Conifer from the Lower Greensand of the Isle of Wight. Ann. Bot. 12: 329-361.

Du Nai-zheng. 1982. The preliminary research on fossil woods from the Palaeocene of Fushun Coal Mine of Liaoning Province, China. Contributions of Research from the Botanical Institute, Acad. Sin. 3: 63-68. (In Chinese with English Abstract.)

Göppert, H.R. 1850. Monographie der fossilen Coniferen. Hollandsche Maatsch. Wetensch. Natuurk. Verh. 6: 196.

Gothan, W. 1905. Zur Anatomie lebender und fossiler Gymnospermen-Hölzer. Abh. Kön. Preuss. Geol. Land., Berlin 44: 1-108.

Greguss, P. 1955. Identification of living Gymnosperms on the basis of xylotomy. Akademiai Kiado, Budapest.

Knowlton, F.H. 1919. A Catalog of the Mesozoic and Cenozoic plants of North America. U.S. Geol. Surv. Bull. 696.

Kräusel, R. 1919. Die fossilen Koniferen-Hölzer. Palaeontographica, Abt. B, 62: 185-275.

Kräusel, R. 1949. Die fossilen Koniferen-Hölzer. II. Kritische Untersuchungen zur Diagnostik lebender und fossiler Koniferen-Hölzer. Palaeontographica, Abt. B, 89: 81-203.

Li Wei-rong. 1986. Late Cretaceous Strata in the Jiayin area, Heilongjiang Province. Regional Geology of China No.1: 28-36. Geological Publishing House, Beijing. (In Chinese with English Abstract.)

Lutz, H.J. 1930. A new species of Cupressinoxylon (Göppert) Gothan from the Jurassic of South Dakota. Bot. Gaz. 66: 92-107.

Seward, A.C. 1919. Fossil Plants IV. Cambridge University Press, London.

Shimakura, M. 1936. Studies on fossil woods from Japan and adjacent lands, contr. I. Sci. Rep. Tohoku Imp. Univ., Sec. Ser. (Geol.). 18: 267-310.

Steward, W.N \& G.W. Rothwell. 1993. Palaeobotany and the evolution of plants. Cambridge University Press, London.

Stopes, M.C. 1915. Catalogue of Mesozoic plants in the British Museum - The Cretaceous flora, part II. Longman, London.

Sze H.G. 1963. Fossil plants of China 2, Mesozoic plants of China. Science Press, Beijing. (In Chinese.)

Vaudois, N. \& C. Privé. 1971. Revision des bois fossiles de Cupressaceae. Palaeontographica, Abt. B, 134: 61-86.

Zhang Shan-zhen \& Cao Zheng-yao. 1986. On the occurrence of Cupressinoxylon from the Jurassic of Anhui. Acta Palaeobot. Palynol. Sinica 1: 23-30. (In Chinese with English Abstract.)

Zhang Zhi-cheng. 1983. The Upper Cretaceous fossil plant from Jiayin region, Northern Heilongjiang. Professional Papers of Stratigraphy and Paleontology 11: 111-132. (In Chinese with English Abstract.)

Zhu Wei-qing. 1983. Studies on the peel method of palaeobotany. Chinese Bull. Bot. 1: 5153. (In Chinese.) 